\title{
TOMASZ KUPŚ
}

(Toruń)

\section{STANOWISKO IMMANUELA KANTA W KWESTII „SIE ŻYWYCH”}

\section{Punkt wyjścia}

W roku 1644 Kartezjusz w Zasadach filozofii - choć wcześniej również w traktacie o świecie - sformułował pogląd, będący przyczyną późniejszego sporu. W paragrafie 36, części II Zasad twierdzi, że ciała uzyskują ruch, jakiego pierwotnie nie miały, w efekcie oddziaływania zawsze z zewnątrz udzielanej siły. Ostatecznym źródłem opisywanej siły jest Bóg, będący jednocześnie gwarantem stałości ilości ruchu w świecie. Chociaż w poszczególnych fragmentach (w ciałach lub ich częściach) ilość ruchu może się zmieniać, to jednak w całości układu (w taki sposób rozważa się tu świat) pozostaje niezmienny. Kwantum ruchu w świecie jest stałe i daje się wyrazić jako iloczyn masy i prędkości $(m v)$.

W marcu roku 1686, w słynnym piśmie naukowym „Acta Eruditorum” Leibniz opublikował łacińską rozprawkę, której polski tytuł brzmi: Krótkie przedstawienie godnego uwagi btędu Kartezjusza $i$ innych względem nadużywanego przez nich w mechanice prawa natury, na mocy którego chca oni, by Bóg zachowywat zawsze te sama ilość ruchu ${ }^{1}$ [= Brevis demonstratio contra cartesianos]. Wspomniany w tytule eseju błąd dotyczy tak zwanej „miary siły”, czyli, używając współczesnych terminów, „matematycznej formuły”, za pomocą której wyrazić można wielkość (quantum) siły.

\footnotetext{
1 Cytuję według tłumaczenia Mikołaja Olszewskego [w:] G. W. Leibniz, Pisma z metafizyki natury, Toruń 1999.
} 
Czynnikiem zmiennym, przy niezmiennej masie ciała, jest bowiem jego prędkość, dlatego w Brevis demonstratio Leibniz pisze, że „matematycy” (nazywa tak zwolenników Kartezjusza) wyrażają siłę ruchem. Rezultatem przyjętej przez „matematyków” „miary siły” jest twierdzenie o zachowaniu w świecie tej samej ilości ruchu. Leibniz przytacza własne argumenty dotyczące swobodnego spadku ciał, z których wynika, że między siłą i ruchem nie istnieje relacja, jaką sformułował Kartezjusz. Uważa bowiem Leibniz, że „zachodzi wielka różnica między siłą poruszającą a ilością ruchu, tak, że jednej nie można obliczyć przez drugą" 2. To znaczy, że nie da się wprost jednej przez drugą wyrazić, albo, innymi słowy, że siła nie jest wprost proporcjonalna do ruchu ciała.

Pomijając opór powietrza oraz tarcie, które ruch ciał w oczywisty sposób zakłócają, to niezależnie od wysokości, z jakiej dokonuje się swobodny spadek ciała, a także bez względu na jego masę, wszystkie ciała mają taką samą siłę, to znaczy wystarczającą do podniesienia ich na początkową wysokość, z której spadek się dokonał. Według ustaleń Galileusza (będących w istocie podstawą miary Kartezjańskiej), prędkość spadającego swobodnie ciała jest wprost proporcjonalna do wysokości, na jakiej znajduje się ciało rozpoczynając swój ruch. Siły ciał spadających z różnych wysokości są te same, ale prędkości różne, co ujawnia błąd równania Kartezjańskiego. Leibniz wnioskuje więc, że do nadania ciału większej prędkości (gdy jest ono położone wyżej) potrzebna jest po prostu większa siła. W roku 1690 i w 1691 Leibniz dwukrotnie występował na łamach wymienionego wyżej czasopisma w obronie własnej miary sił przeciwko zwolennikom miary ustalonej przez Kartezjusza (w eseju z 1690 sformułował nawet teoretyczny model maszyny, zdolnej dostarczać samej sobie siły niezbędnej do utrzymania ruchu; Kant w § 92 rozprawy Myśli o prawdziwej mierze sił żywych referuje tę hipotezę perpetuum mobile).

Największe znaczenie problemu ,sił żywych” ma jednak rozprawka opublikowana przez Leibniza dopiero w roku 1695, zatytułowana Specimen dynamicum pro admirandis naturae legibus circa corporum vires et mutuas actiones detegendis et ad suas causas revocandis [= Specimen dynamicum]. Leibniz rozróżnia tu dwa rodzaje dążności (nisus, albo inaczej conatus). Dążność pierwszego rodzaju ma charakter elementarny i jest nieskończenie mała (solicitatio), natomiast druga, jest wynikiem kontynuacji ruchu raz nadanego albo powstajaccego w wyniku powtarzania owego nisus. Tę dążność Leibniz nazywa impetus. Leibniz dokonał podziału w obrębie sił ciał znajdujących się w ruchu i wprowadził nazwy (siła żywa [vis viva] oraz siła martwa [vis mortua]) które dziś, choć nieaktualne, mają swoje odpowiedniki w pojęciu siły kinetycznej [vis viva] i siły bezwładności [vis mortua]. Leibniz

2 Brevis demonstratio, s. 75. 
podaje jednocześnie przykłady ruchów, przyporządkowując im odpowiednie siły. Siłą martwą jest na przykład siła odśrodkowa, siła ciążenia oraz siła pozwalająca sprężystemu ciału wrócić do pierwotnego kształtu. Jest to siła, której nie odpowiada rzeczywisty ruch (to znaczy trwające określony czas przemieszczenie ciała). Siła żywa natomiast przypisana została ciałom, które swobodnie kontynuują ruch, raz nadany im w wyniku uderzenia. W rozprawce tej nie zostaje podane żadne równanie, jednak z argumentacji Leibniza wyłania się wniosek, że miarą jej powinien być iloczyn masy i kwadratu prędkości $\left(m v^{2}\right)$.

Podobnie jak w przypadku Kartezjusza, również stanowisko Leibniza, jest tak samo raczej wynikiem spekulacji, niż przyrodniczych badań. Pojęcie siły działają$\mathrm{cej}^{3}$, określającej najbardziej wewnętrzną naturę ciała (zastosowane w Specimen dynamicum), jest pojęciem czysto metafizycznym.

Właśnie do tego sporu odnosi się Kant w rozprawie Myśli o prawdziwej mierze sit $\dot{z} y w y c h^{4}$. Stanowisko królewieckiego filozofa samo w sobie nie jest oryginalne, jednak zawiera ważne rozstrzygnięcia charakterystyczne zarówno dla sposobu uprawiania przez Kanta filozofii w pierwszym okresie jego twórczości, jak i dla pewnych wątków filozofii krytycznej. Gotthold Ephraim Lessing w uszczypliwym czterowierszu pokpiwa sobie nawet z młodego filozofa, sugerując, że naiwnie nie oszacował realistycznie własnych sił, porywając się na miarę sił żywych ${ }^{5}$. Wprawdzie Kant zapowiada śmiało, że nie licząc się z powszechną wiarą w utrwalone autorytety zamierza rozstrzygnąć spór, jaki toczy się między zwolennikami dwu szkół, jednak nie tylko myli się podając własne rozwiązanie, ale również nie jest świadomy faktu, że właściwą formułę już ogłoszono. W 1743 roku dokonał tego d'Alembert w Traité de dynamique $\left(K=\frac{1}{2} m \cdot v^{2}\right)$.

Opublikowana w roku 1747 rozprawa Kanta ukończona została trzy lata wcześniej. Dwudziestodwuletni wówczas autor usiłuje tu doprowadzić do kompromisu. Podane przez niego rozwiązanie polega na przyjęciu dwóch miar, miary zwolenników Leibniza $\left(K=m \cdot v^{2}\right)$ ale tylko w odniesieniu do „sił żywych” (to znaczy „ruchów swobodnych”) oraz miary Kartezjańskiej w odniesieniu do „sił martwych” (to znaczy ruchów nieswobodnych).

Z naszej perspektywy najważniejsze jest znaczenie, jakie w dyskusji tej przypisuje się sile żywej. Kant pozostaje tu bowiem pod silnym oddziaływaniem poglą-

\footnotetext{
3 W polskim przekładzie Specimen dynamicum zastosowano wyrażenie „siła czynna” (Leibniz, dz. cyt., s. 79).

4 Wydanie polskie: I. Kant, Myśli o prawdziwej mierze sił żywych, przeł. M. Jankowski, T. Kupś, R. Michalski, A. Pacholik-Żuromska, D. Pakalski, M. Żelazny, [w:] tenże, Dzieła zebrane, t. 1, Toruń 2010, s. 13 i nast.

5 Parafrazuję tu czterowiersz Lessinga, który podaje E. Adickes: „Kant unternimmt ein sicher Geschäfte, / Der Welt zum Unterricht. / Er schätzet die lebendigen Kräfte; / Nur seine schätzt er nicht." (Lessing Sämtliche Schriften, wyd. Lachmann-Muncker, wyd. 3, 1886, t. 1, s. 41, cyt. za E. Adickes, Kant als Naturforscher, Berlin 1924, t. 1, s. 69).
} 
dów Leibniza, a jego rozstrzygnięcie, sięga znacznie poza kwestie czysto fizykalne, w których jest dyletantem. Na początku Specimen dynamicum, wspomnianej już rozprawki Leibniza, w której dokonany zostaje podział na siły żywe i siły martwe, znajduje się znamienna deklaracja:

(...) w rzeczach cielesnych jest coś poza rozciągłością (extensio), coś co jest nawet wcześniejsze od rozciągłości, a mianowicie owa rozmieszczona wszędzie przez Stwórcę siła natury. Nie polega ona na prostej zdolności (facultas), którą, jak się zdaje, zadowala się szkoła. Siła ta została ponadto wyposażona w usiłowanie (conatus), czyli dążność (nisus), które odnosi pełny skutek, jeżeli nie przeszkodzi mu usiłowanie przeciwne. Zmysły spostrzegają ową dążność wszędzie, rozum zaś - moim zdaniem - rozpoznaje ją w każdej części materii, także tam, gdzie nie jest ona dostrzegana przez zmysły 6 .

Musimy więc przyjąć, że - zdaniem autora Monadologii - ciała mogą zawierać siłę, nie wyrażającą się w ruchu (to znaczy nie dostrzeganą przez zmysły). Na tym tle dopiero widać wyraźniej, w jaki sposób Kant interpretuje spór o nature sił. Konflikt toczy się w istocie nie tyle o miarę sił, co raczej o naturę ciał. Kant wyraźnie opowiada się tu po stronie Leibniza (por. $§ 9$ rozprawy Kanta). Dostrzega w nim przede wszystkim zderzenie zwolenników mechanicyzmu (kartezjańskich matematyków) oraz zwolenników teleologii (leibnizianistów). Mamy bowiem następującą alternatywę, albo oddziaływania między rzeczami (zjawiskami) rozważać będziemy jako efekt czysto mechanicznego udzielania ruchu, którego źródłem jest siła, zawsze leżąca poza ciałem. Albo przypuścimy możliwość rozpatrywania pewnych ruchów, czy działań, jako efektu wewnętrznego dążenia (determinacji wewnętrznej natury ciała). Intencję tego rozróżnienia widać w odpowiadającej mu alternatywnej terminologii, w której siła martwa nazywana jest siłą nieswobodną (w sensie związaną, zdeterminowaną, zależną), zaś siła żywa - siłą swobodną (w sensie niezależną, a odpowiadający jej ruch, ruchem swobodnym). Przez ruch swobodny, należy rozumieć taki ruch, który wywołany jest siłą żywą (§ 18) i „utrzymuje się sam z siebie w pustej przestrzeni” (Myśli o prawdziwej mierze sił żywych..., § 17). Ruch planet w Układzie Słonecznym jest przykładem takiego ruchu. Pozostawiam bez odpowiedzi, czy „swobodę” tę należy rozumieć jako zdolność do działania „wolnego” od zewnętrznego nacisku, a więc takiego działania, które nie wymaga, jak przy ścisłym mechanizmie, oddziaływania zewnętrznych przyczyn.

6 Specimen dynamicum, s. 77. Por. także I. Kant, O zastosowaniu metafizyki, o ile jest ona połaczona z geometria, w filozofii przyrody, której pierwsza próba zawiera monadologie fizyczna, [w:] tenże, Dziela zebrane, t. 1, Toruń 2010, s. 437 i nast. 
W tym miejscu zarysowuje się już, znana dopiero z późniejszych rozpraw Kanta, różnica między porządkiem zjawisk, w których właściwy im sposób poznania sprowadza istniejące między nimi zależności do czystego mechanizmu oraz porządkiem wolności, w którym mam prawo do postulowania innej przyczynowości, aniżeli przyczynowość mechaniczna. W Myślach o prawdziwej mierze sit żywych Kant zajmuje stanowisko kompromisowe, ale konsekwencje tego kompromisu widoczne będą również w jego późniejszych rozprawach, niezależnie już od rozstrzygnięć dotyczących samych kwestii fizykalnych.

\section{Stanowisko Kanta}

W podstawowej warstwie treść pierwszej rozprawy Kanta sprowadza się do uzasadnienia kompromisowego rozwiązania sporu. Polega ono na utrzymaniu dwóch miar ${ }^{7}$, w odniesieniu do dwóch, wyróżnionych przez Leibniza rodzajów sił. Z perspektywy późniejszych rozpraw Kanta nie jest to wątek najważniejszy.

Dzieło Kanta, rozpatrywane jedynie w kategoriach naukowych, musiałoby zostać ocenione jako reprezentujące poziom niższy od przeciętnego poziomu ówczesnej wiedzy $^{8}$. Sposób rozumienia natury sił żywych pozostaje tu w sprzeczności z zasadniczą tendencją w ówczesnym przyrodoznawstwie. Wprowadzając pozbawione regularności zanikanie i powstawanie sił żywych i ruchu ciał ${ }^{9}$, sprzeciwia się Kant zarówno zasadzie równości działania i przeciwdziałania, jak i zasadzie bezwładności. Przy czym pokłada zaufanie w mądrości Boga, który nie pozwolił, ażeby taki stan rzeczy przekształcił się w chaos ${ }^{10}$. Temat pierwszej rozprawy jest więc wprawdzie czysto przyrodoznawczy, jednak Kant nie zajmuje tu stanowiska konsekwentnego przyrodnika. Ujawnia się to zwłaszcza przy porównaniu z pracami takich przyrodników, jak Euler, Musschenboeck, Johann Bernoulli, d'Alembert. Teminologia Kanta jest nieostra, nieprecyzyjna i zmienna ${ }^{11}$. Autor wyraźnie wikła się w spór między szkołami zwolenników Kartezjusza i Leibniza, jednak usiłuje go rozwiązać w sposób czysto filozoficzny a nie naukowy. Dlatego w istocie odnosi się do określenia perspektywy interpretacji zjawisk w ogóle bądź to w kategoriach czysto mechanicznych, bądź teleologicznych.

\footnotetext{
7 I. Kant, Myśli o prawdziwej mierze sil żywych oraz ocena dowodów, którymi w tej spornej kwestii postugiwat się Leibniz i inni mechaniści wraz z kilkoma wstępnymi uwagami dotyczacymi ciał w ogóle, [w:] tenże, Dzieła zebrane, t. 1, Toruń 2010 (chodzi o $\S 22$, s. 41-42).

8 E. Adickes, Kant als Naturforscher, t. 1, wyd. cyt., s. 139.

9 I. Kant, Myśli o prawdziwej mierze sil żywych, $\S 136$, wyd. cyt.

10 Tamże, § 49-51.

11 E. Adickes, Kant als Naturforscher, t. 1, wyd. cyt., s. 137 i nast.
} 
Bez wątpienia zadziwia śmiałość młodego autora, skłonność do schodzenia z utartych ścieżek standardowego rozumienia rzeczy, nastawienie na szeroką syntezę, bogactwo idei, dar przenikliwych intuicji. Takie oceny formułuje wobec Kanta Adickes, zwracając uwage na poboczne wątki rozprawy.

Nie można z pewnością poczytać Kantowi za błąd, że mimo wywołanego tematem rozprawy złudzenia rozważań czysto przyrodoznawczych, pozostaje metafizykiem (uwikłanym w metafizycznej natury spór między zwolennikami Kartezjusza i stronnikami Leibniza). Być może najwyraźniej widać to w początkowych paragrafach pracy, zawierających jedynie spekulatywne rozważania nad sposobem rozumienia siły. Ujawnia się tu zamiar ostatecznego rozstrzygnięcia sporu na płaszczyźnie czysto teoretycznej. Już tutaj, podobnie jak w późniejszych dziełach, zwłaszcza w Metaphysische Anfangsgründe der Naturwissenschaft oraz w Opus postumum, na plan pierwszy wysunie się idea apriorycznej dedukcji warunków całości doświadczenia. Nie ulega też zmianie przekonanie Kanta o konieczności ustalenia metafizycznych podstaw, na których będzie mogła się wspierać ta, czy inna postać nauki o przyrodzie.

Wbrew ściśle mechaniczno-matematycznemu ujęciu Kartezjusza Kant przystępuje do dynamiczno-metafizycznego stronnictwa zwolenników Leibniza. Również zaproponowane przez niego rozwiązanie problemu właściwej miary sił jest bardziej metafizyczne niż przyrodnicze. W $§ 50$ Kant pisze o siłach żywych wprost, że „w sposób, w jaki zabrano się do ich [udowodnienia], nigdy nie powinny być odkryte i że temu rodzajowi rozumowania (mianowicie matematycznemu) pozostają one na zawsze niedostępne" 12. A nawet, że ciała, o jakich mówią „matematycy”, to jedynie utworzone na podstawie pojęć konstrukcje zupełnie różne od ciał naturalnych.

Adickes zwraca uwagę na widoczną już w tej rozprawie metodologiczną tendencję Kanta, by w rozważaniach oddzielać materię poznania od jego formy. W przywołanym $\S 50$ Kant podkreśla, że krytyce poddaje nie tyle samą sprawę, lecz jej modus cognoscendi. Daje się więc już tutaj dostrzec skłonność filozofa do podejmowania krytyki poznania, zainteresowanie metodą i źródłem wiedzy o naturze sił. Dlatego też, jak podkreśla Adickes, Cassirer ma prawo nazwać ten traktat „rozprawą o metodzie”. Z kolei w $§ 58$ znajdujemy przykład, tak charakterystycznej, zwłaszcza dla późniejszej dialektyki czystego rozumu, metody antytetycznej (rozpatrywania poglądów przeciwnych), a w konsekwencji ambicję do odgrywania arbitra między spornymi tendencjami: empiryzmem i racjonalizmem, determinizmem i indeterminizmem, a w omawianej rozprawie, między Kartezjuszem i Leibnizem.

12 Tamże, s. 140 i nast. 
Kluczowe znaczenie ma metafizyczne twierdzenie (przyjęte za Leibnizem w $\S 1$ ), że ciała maja „siłę istotną”, która przysługuje im „przed rozciągłością" 13 . Konsekwencją tego założenia jest zastąpienie „siły poruszającej” (vis motoris) „siłą działającą" (vis aktiva), by możliwe było przypisanie tej siły wszelkim ciałom, których działanie nie musiałoby się sprowadzać jedynie do przemieszczania. Przestrzenność ciał ukazana zostaje jako wtórna wobec sił istotnych materii. „Przestrzenność", podobnie jak w Monadologii fizycznej „cząstka”, jest jedynie polem działania siły. Formą działania jest tu również „wywoływanie przedstawień", zaś związek ciał z duszą „odbiciem uniwersum” 14.

W konsekwencji, z łatwością przyjmuje Kant również możliwość istnienia rzeczy nierozciągających się w przestrzeni trójwymiarowej, a dalej, także możliwość istnienia nie tylko wielości takich bytów, ale i systematycznego związku między nimi. W efekcie wykazuje, że nie ma podstaw, by a priori odrzucić możliwość istnienia takiego „szczególnego świata” ${ }^{15}$. Z pewnością tutaj leży źródło późniejszej koncepcji mundus intelligibilis, dającego się jedynie pomyśleć moralnego porządku istot zdolnych postępować w sposób niezależny od konieczności zmysłowej przyrody, które ustanawiaja system istot podlegających moralnemu prawu, a więc ideał królestwa celów.

\section{Hipotezy}

Późniejsze stanowisko Kanta nie jest w kwestii sił żywych ani stałe, ani nie układa się w spójną całość. Znawca spuścizny rękopiśmiennej Kanta, Erich Adickes, uważa, że w notatkach z lat siedemdziesiątych filozof zrezygnował ze swego wcześniejszego stanowiska i przyjął czysto kartezjański pogląd na kwestię miary sił. Obierając dla wszystkich sił jednakową, kartezjańską miarę $(m v)$. Paradoksem pozostaje jednak, że zachował przy tym Leibniziański podział na siły martwe i żywe ${ }^{16}$, by parę lat później znowu powrócić do obu miar.

13 Por. Specimen dynamicum, wyd. cyt., s. 77 oraz „(...) jeśli ciało w ogóle ma siłę żywą, gdy przez pewien czas było w ruchu (...), to musi mieć ją również wtedy, gdy dopiero ruch rozpoczyna". Por. także. G. W. Leibniz, Poprawa filozofii pierwszej i pojęcie substancji, przeł. S. Blandzi, [w:] tenże, Pisma z metafizyki natury, wyd. cyt., s. 15. Znaczy to, że ciało nie zyskuje siły żywej dopiero po pewnym czasie, ale że ma ją już uprzednio, zaś jej ujawnienie następuje natychmiast, gdy usunięte zostaną przeszkody (na przykład sznur wstrzymujący zawieszone ciało; Myśli o prawdziwej mierze sit żywych, $§ 27$, wyd. cyt.).

14 I. Kant, Myśli o prawdziwej mierze sit żywych, § 6, wyd. cyt.

15 Tamże, $\S 8$.

16 AA, t. XIV, s. 196 i nast. 
Wahania Kanta w tej sprawie są chyba zrozumiałe, zważywszy, że przyjmowanie w obrębie przyrodoznawstwa różnych miar ruchu jest niedopuszczalne ${ }^{17}$. Coraz wyraźniej priorytetem dla Kanta staje się zamiar uzasadnienia systematycznej jedności doświadczenia świata, widoczny zwłaszcza w późnych rozprawach (dostrzegamy go począwszy od refleksji historiozoficznej, teleologicznej i religijnej, a na dedukcji istnienia eteru kończąc). Kluczowe jest w tym wypadku doświadczenie wyprzedzające wszelkie czysto spekulatywne rozważania możliwości. Takim wstępnym doświadczeniem jest doświadczenie żywego organizmu oraz doświadczenie siebie, jako źródła siły poruszającej ${ }^{18}$. Jedynie to wstępne doświadczenie pozwala nam zrozumieć, czym jest siła (jako „subiektywna możliwość bycia przyczyną" ${ }^{19}$ ). W tej sytuacji ,życie” nie byłoby wyjątkowym przypadkiem doświadczenia, ale warunkiem doświadczenia w ogóle.

Przykładem tego ciągłego wahania się filozofa są wypowiedzi zawarte w $M e$ taphysische Anfangsgründe der Naturwissenschaften (1786), gdzie Kant wraca do stanowiska Kartezjańskiego (w szczególności Lose Blätter, D 28) i gdzie eliminuje miarę $m v^{2}$ :

Ilość ruchu ciał odpowiada [iloczynowi] ilości ich materii oraz prędkości, to znaczy obojętne jest, czy podwoję ilość materii, zachowując tę samą prędkość, czy podwoję prędkość, zachowując tę samą masę. Albowiem, określone pojęcie wielkości jest możliwe tylko dzięki konstruowaniu [opartemu na stosunkach] ilościowych $[\text { Quantum }]^{20}$.

Kant zamierza również usunąć różnicę między siłą martwą i żywą, choć materiał do tego rodzaju porównań znajdziemy dopiero w notatkach z Opus postumum (z lat 1795-1801). Po przywołanych wyżej słowach z Metafizycznych podstaw przyrodoznawstwa podane zostaje uzasadnienie dla zachowania w tej sytuacji dwóch nazw sił.

Ci, którzy za miarę całego oddziaływania przyjmowali tylko wielkość przestrzeni stawiającej opór (na przykład, wysokość, do której ciało wznosi się z tą albo inną prędkością mimo [= pokonując] ciężaru [Schwere], albo głębokość, do której ciało to zdolne jest zanurzyć się w miękkich substancjach), wyprowadzili inne prawo sił poruszających w przypadku rzeczywistych ruchów, a mianowicie [prawo]

17 Por. R. Spaemann, R. Löw, Cele naturalne, przeł. A. Półtawski, Warszawa 2008.

18 Tamże, s. 162 i nast. Ten sposób myślenia, w którym doświadczenie poprzedza czysto spekulatywne rozważanie możliwości, jest cechą charakterystyczną dowodu ontoteologicznego, jaki formułował Kant w pismach przedkrytycznych.

19 I. Kant, Opus postumum (AA XXII, s. 192).

20 I. Kant, Metaphysische Anfangsgründe der Naturwissenschaften, [w:] Kants Werke, Akademie-Textausgabe, Berlin 1968, t. 4, s. 539. 
ilości materii w stosunku do kwadratów ich prędkości (...). Nie może więc być również różnicy między żywymi i martwymi siłami, jeśli siły poruszające rozpatrywane będą mechanicznie, tj. jako takie, którymi obdarzone są ciała, które same zostały poruszone, wszystko jedno, czy prędkość ich ruchu będzie skończenie czy nieskończenie mała (a nawet wówczas, gdy będzie tylko dążeniem do ruchu). Byłoby bardziej właściwym nazywać martwymi te siły, za pomoca których jedna materia działa na inną, całkowicie abstrahując od własnego ruchu [owej materii] a nawet od jej dążenia do poruszania się, wobec tego pierwotnie poruszające siły dynamiki [nazywać będziemy] siłami martwymi [tote folglich die ursprünglich bewegende Kräfte der Dynamik Kräfte], wszystkie mechanicznie, tj. siły poruszające dzięki własnemu ruchowi, nazywać będziemy siłami żywymi, nie zwracając uwagi na różnicę w prędkości, której stopień może być również nieskończenie mały, jeśli tylko w ogóle te nazwy - siła martwa i siła żywa - należy zachować ${ }^{21}$.

Wspomina o tym Kant jeszcze w niepublikowanych rękopisach (Handschriftlicher Nachlass, (AA XIV, s. 196 i nast.; s. 456 i nast.; [Berliner Physik] s. 201) i w wielu miejscach Opus postumum (chciałbym jedynie nawiązać do zbioru dwunastego $\left.^{22}\right)$.

Nauka jako całość możliwa jest tylko dzięki przyjęciu metafizycznych założeń. W Metafizycznych podstawach przyrodoznawstwa Kant wciąż jeszcze trwa przy idei uniwersalnej Newtonowskiej mechaniki, jako podstawy jednolitego systemu wiedzy o przyrodzie. Ta perspektywa zostanie jednak otwarta dopiero dzięki nowym koncepcjom dynamiki procesów naturalnych (w chemii, elektryczności, magnetyzmie).

Z perspektywy Opus postumum nawiązanie do najwcześniejszej pracy o siłach żywych widać w próbach zbudowania systemu materii nie w oparciu o teorię ruchu ciał (cząstek, jak w Powszechnej historii naturalnej $i$ teorii nieba czy w O ogniuto znaczy prac, w których Kant jawi się jako mechanicysta ${ }^{23}$ ) ale jako teorii sił. Zasadą tej jedności ma być eter. Należy zwrócić uwagę, że istnieje tendencja, by tę część jego dorobku interpretować wyłącznie z perspektywy dynamiki. Wydaje mi się jednak, że rozważania te można odczytywać na dwa sposoby.

Po pierwsze, nadal jeszcze korpuskularnie, w duchu rozprawy O ogniu, jako wynik mechanicznego oddziaływania eteru (materii ognia) na elementarnym poziomie materii. W tej perspektywie „zewnętrzną” przyczyną spójności jest „materia ognia":

\footnotetext{
21 Tamże, s. 539.

22 Fragmenty tej części Opus postumum publikowane są w kolejnych numerach „Studiów z Historii Filozofii" (nr 1-3).

23 Wymienione rozprawy zostały opublikowane w polskim przekładzie w tomie 1 Dziet zebranych Kanta (Toruń 2010).
} 
Spójność [Cohaesion] jest trwałym oddziaływaniem tej siły [tj. siły żywej], zaś jego przyczyną sprawczą jest materia ciepła ${ }^{24}$.

Po drugie, dynamicznie, jako efekt oddziaływania sił pierwotnych materii. W zbiorze dwunastym Opus postumum przeważa właśnie ta druga interpretacja, zgodnie z którą spójność materii zachowywana jest dzięki obecności istotnej siły żywej:

Spójność [die Cohäsibilität] jest oddziaływaniem siły żywej ${ }^{25}$.

Przyczyna spójności [Cohäsibilität] (siły poruszającej materię do kohezji) tego, co sztywne, sama musi być niespójna [incohäsibel], ponieważ jest siłą przenikającą[.] Poruszającą się materię należy wyobrazić sobie jako objętą ruchem rzeczywistym, a mianowicie [ruchem] uderzenia, które równa się nieskończonemu momentowi, i stanowi siłę żywą przenikającej materii ${ }^{26}$.

Przyjęcie wewnętrznej siły poruszającej, zapewniającej sztywność i spójność ciał, traktuje Kant jako konieczny warunek dynamiczny możliwości wyjaśnienia zjawisk mechanicznych, bez czego każde wyjaśnienie popadałoby w circulus vitiosus.

Musi istnieć nieważka materia, która dzięki wewnętrznemu ruchowi części ważkiego ciała, wprawia [ciała] w ruch nie mechanicznie, lecz dynamicznie (nie dzięki zewnętrznym, lecz dzięki wewnętrznym siłom poruszającym), inaczej bowiem wyjaśnienie nie wychodziłoby poza błędne koło 27 .

Natomiast w § 9 Myśli o prawdziwej mierze sit żywych pisze:

Łatwo wykazać, że nie byłoby ani przestrzeni, ani rozciągłości, gdyby substancje pozbawione były siły zewnętrznego działania. Przeto bez tej siły nie ma żadnego powiązania, żadnego porządku, a nawet przestrzeni ${ }^{28}$.

W próbach sformułowania ostatniego dzieła powraca myśl, jaka wyrażona została już w pierwszej rozprawie Kanta. Interpretacja zatacza krąg i wraca w ten sposób do punktu wyjścia.

24 I. Kant, Opus postumum, Kant's handschriftlicher Nachlaß, [w:] tenże, Gesammelte Schriften, t. XXII, Berlin und Leipzig 1938, s. 574.

25 Tamże, s. 537.

26 Tamże, s. 582-583.

27 Tamże, s. 189.

28 I. Kant, Myśli o prawdziwej mierze sit żywych, § 9; por. K. Fischer, Immanuel Kant und seine Lehre, Heidelberg 1957, s. 158. 


\section{Summary}

In his first work entitled "Thoughts Concerning the True Measure of Vital Forces" Kant made an attempt to solve one of the most famous disputes of 17th-century philosophy. Though Kant's solution is incorrect, it shows the way the philosopher usually solved philosophical problems. In his later works, written during the critical period, Kant came back to the problems he dealt with in his first essay, but the most important continuation of it can be found in the unpublished notes being part of so-called Opus postumum.

\section{Bibliografia}

E. Adickes, Kant als Naturforscher, Berlin 1924.

K. Fischer, Immanuel Kant und seine Lehre, Heidelberg 1957.

Kants Werke, Akademie-Textausgabe.

I. Kant, Myśli o prawdziwej mierze sit żywych, przeł. M. Jankowski, T. Kupś, R. Michalski, A. Pacholik-Żuromska, D. Pakalski, M. Żelazny, [w:] tenże, Dzieła zebrane, t. 1, Toruń 2010.

G. W. Leibniz, Pisma z metafizyki natury, Toruń 1999.

R. Spaemann, R. Löw, Cele naturalne, przeł. A. Półtawski, Warszawa 2008.

Dr hab. Tomasz Kupś, Instytut Filozofii, Uniwersytet Mikołaja Kopernika Miejsce zatrudnienia (i adres korespondencyjny): Instytut Filozofii UMK, ul. Fosa Staromiejska 1a, 87-100 Torun,

e-mail: kups@umk.pl 